\title{
Analysis of Integrated Design in Green Ecological Architecture
}

\author{
Chuang Wang ${ }^{1}$, Fangyuan Zheng ${ }^{1}$, Guoming Dai ${ }^{2}$ \\ 1. College of architecture and urban planning, Nanyang Institude of Technology, Nanyang 473000, China \\ 2. Architecture Design Institute, Nanyang Institude of Technology, Nanyang 473000, China
}

Keywords: Green architecture; Integrated design; Energy saving

\begin{abstract}
Integrated design is an important principle of modern green ecological building design. The integrated design system of ecological architecture covers six aspects, including architecture optimization, energy optimization, material optimization, environmental optimization, control optimization and economic optimization, each of which contains different subsystems, technical systems and specific technical means. With the green architecture design system, architects would be also to fully grasp the ecological architecture design process.
\end{abstract}

\section{Introduction}

Green ecological architecture is the future development trend of China's construction industry, because it would maximize resources, protect the environment and reduce pollution within its full life cycle. Green ecological architecture requires full consideration of environmental protection, energy saving, economy, comfort and other comprehensive factors in the design, construction and utilization process. Therefore, to a great extent, architecture design capability determine the development of green ecological architecture.

With the development of modern design concept and the popularization of green architecture design consciousness, architects no longer only focus on the plane function, solid modeling and construction techniques of the architecture, but gradually evolved into an integrated design of multidisciplinary integration.

Different from traditional design methods, integrated design guarantees the introduction of various professional information at the initial stage of design, and consider all the factors and the possibilities of the design at the beginning of the design, mainly reflecting in two aspects: one is vertical comparison, that is, think of the architecture itself as a whole with the outside world, and take the building life cycle as the starting point for design decisions; another is horizontal comparison, which requires all the professional designers to work closely together, to integrate sustainable architectural design strategies in terms of functionality, form, performance, and economics.

\section{Green Architecture Integrated Design Process}

To achieve integrated design, on the one hand, it needs to design a team of professional designers and other experts at the initial stage of the project. Architects, in general, are team leaders and coordinators, but not the only policy maker. Architects must have the knowledge of technical solutions, and meanwhile, engineers must also have a thorough understanding of the complexity of the building design process. On the other hand, the traditional design process needs to be converted from a linearized process into an annular process, where improvement of program design, preliminary design and construction drawing design process should be focused.

\section{Conceptual design phase}

In conceptual design phase, the expertise of architects and engineers integrates and inspires each other, to meet architecture construction demand. At the same time, the following factors should be 
taken into account: requirements for architectural design, work or living environment and visual effects; requirements of function, structure, energy consumption and indoor environment quality; other quality indicators such as building performance, thermal comfort, outdoor landscape and so on.

In this phase, through the deepening of the design scheme, it can meet the requirements of indicators and other requirements in the design process. In the meantime, various professional information related to Architectural design is deeply integrated.

The prerequisites for designing energy-efficient buildings or green buildings are as follows: in conceptual design phase, the design team must continually evaluate the architectural form, plane layout, construction plan, building direction, structure mode used in the program, and according to the requirements for heating, cooling, ventilation and lighting, as well as the impact of climate on building energy efficiency, to optimize the combination of these factors, so as to ensures that these factors are optimal for building function and energy environment.

\section{Preliminary design phase}

The target in preliminary design phase is to determine the final form of the architecture, and make it meet the design intent. In this phase, designers must integrate all the factors considered in conceptual design phase, including general layout, architectural form, function, space design, interior layout, relevant specification, indoor environment technology and energy solutions. Various factors in the program should be optimized, and meanwhile simulate and calculate the results of building energy and indoor environmental performance.

It requires types of tools to provide guidance for designers: one is simulation tools, which are used to provide decision reference for the design team for technical integration and optimization of the project; another is design guidance tools, which are used provide guidance for the energy saving optimization of the overall and system parts of the architecture. In addition, materials and equipment parts database should be prepared, so that designers can choose based on optimization results.

Thus, every part of the building can "perform their duties", and even additional performance may be enhanced.

\section{Drawing design phase}

In construction drawing design phase, technical solutions should be improved, and work with the engineering contractor, the equipment dealer and the material supplier to determine the specifications and models of the relevant products, and then complete the final drawing. The final construction data and specifications must comply with specifications, measurements and inspection requirements, and it also includes the elaboration and interpretation of the necessary energy and environmental performance. The results of energy and environmental analysis should be consistent with the design implementation process, as well as energy simulation and computation, and comparative analysis of cost and benefit, etc.

In this phase, which is mostly used is comprehensive evaluation tool, whose purpose is to provide decision reference for material parts and technology selection. Moreover, to ensure the quality of the completed project, detailed instructions on the construction process requirements should be prepared as much as possible, so as to avoid raising costs or delaying construction periods.

\section{Construction of Green Architecture Integrated Design System}

The basic starting point of eco-architecture integrated design is the concern of the whole life cycle of the architecture, including full cycle process of raw material mining, planning design, transportation, operation, maintenance, until demolition and disposal.

Starting from the sustainable goal of ecological architecture design, in order to facilitate architects to design ecological architecture, we use the method of systematic integration to comprehensively analyze all aspects of the whole life cycle of the architecture, combined with 
comprehensive evaluation of environmental benefit, social benefit and economic benefit, so we have initially put forward six systems for green architecture integrated design: architectural design optimization system, energy design optimization system, material saving and waste disposal system, environment design optimization system, intelligent control system and economic balance system, each of which contains different subsystems, technical systems and specific technical means, as shown in Table 1.

Table 1. Green architecture integrated design system

\begin{tabular}{|c|c|c|c|}
\hline System & Subsystem & Technical system & Specific technical means \\
\hline \multirow{18}{*}{$\begin{array}{l}\text { Architecture } \\
\text { optimization } \\
\text { system }\end{array}$} & \multirow{4}{*}{$\begin{array}{l}\text { Site design } \\
\text { optimization }\end{array}$} & Location optimization & $\begin{array}{l}\text { Sunshine, ventilation and terrain } \\
\text { analysis }\end{array}$ \\
\hline & & Traffic optimization & Traffic for vehicles \\
\hline & & $\begin{array}{l}\text { Vegetation } \\
\text { optimization }\end{array}$ & $\begin{array}{l}\text { Vegetation distribution, plant } \\
\text { configuration }\end{array}$ \\
\hline & & Water utilization & $\begin{array}{l}\text { Rainwater collection, treatment } \\
\text { and reuse }\end{array}$ \\
\hline & \multirow{3}{*}{$\begin{array}{l}\text { Function } \\
\text { space } \\
\text { optimization }\end{array}$} & Area saving & Simultaneous combination \\
\hline & & $\begin{array}{l}\text { Reuse of function } \\
\text { space }\end{array}$ & Variable internal space \\
\hline & & $\begin{array}{l}\text { Rational distribution } \\
\text { of functional areas }\end{array}$ & Passive insulation space \\
\hline & \multirow{3}{*}{$\begin{array}{l}\text { Structural } \\
\text { system } \\
\text { optimization }\end{array}$} & $\begin{array}{l}\text { Structural system } \\
\text { optimization }\end{array}$ & Structure selection \\
\hline & & $\begin{array}{l}\text { Enclosure structure } \\
\text { optimization }\end{array}$ & Insulation layer arrangement \\
\hline & & $\begin{array}{l}\text { Door and window } \\
\text { system }\end{array}$ & Low-E glass \\
\hline & \multirow{4}{*}{$\begin{array}{l}\text { Equipment } \\
\text { system } \\
\text { optimization }\end{array}$} & Pipeline optimization & Pipeline consolidation \\
\hline & & $\begin{array}{l}\text { Air conditioning } \\
\text { system optimization }\end{array}$ & Pipeline consolidation \\
\hline & & $\begin{array}{l}\text { Water system } \\
\text { optimization }\end{array}$ & Reclaimed water recycling \\
\hline & & $\begin{array}{l}\text { Power system } \\
\text { optimization }\end{array}$ & Wireless LAN control technology \\
\hline & \multirow{2}{*}{$\begin{array}{l}\text { Decoration } \\
\text { system } \\
\text { optimization }\end{array}$} & $\begin{array}{l}\text { Interior decoration } \\
\text { material optimization }\end{array}$ & $\begin{array}{l}\text { Microcrystalline stone and nano } \\
\text { antibacterial coating }\end{array}$ \\
\hline & & $\begin{array}{l}\text { Exterior decoration } \\
\text { material optimization }\end{array}$ & Local material usage \\
\hline & \multirow{2}{*}{$\begin{array}{l}\text { Construction } \\
\text { scheme } \\
\text { control }\end{array}$} & Material transportation & Local material usage \\
\hline & & $\begin{array}{l}\text { Construction site } \\
\text { control }\end{array}$ & Field environmental control \\
\hline \multirow{9}{*}{$\begin{array}{c}\text { Energy } \\
\text { optimization } \\
\text { system }\end{array}$} & \multirow{5}{*}{$\begin{array}{l}\text { Energy } \\
\text { saving }\end{array}$} & Natural draft & $\begin{array}{l}\text { Air pressure ventilation and hot } \\
\text { pressing ventilation }\end{array}$ \\
\hline & & Shading system & $\begin{array}{l}\text { Exterior sunshade and inner } \\
\text { sunshade }\end{array}$ \\
\hline & & Natural lighting & $\begin{array}{l}\text { Illumination of refracting plate and } \\
\text { lighting well }\end{array}$ \\
\hline & & $\begin{array}{l}\text { Natural potential } \\
\text { energy }\end{array}$ & $\begin{array}{l}\text { Utilization of terrain elevation } \\
\text { difference }\end{array}$ \\
\hline & & $\begin{array}{l}\text { Retaining structure } \\
\text { insulation }\end{array}$ & $\begin{array}{l}\text { Hot broken aluminum alloy } \\
\text { window }\end{array}$ \\
\hline & \multirow{4}{*}{$\begin{array}{l}\text { Clean energy } \\
\text { use }\end{array}$} & $\begin{array}{l}\text { Solar energy } \\
\text { utilization }\end{array}$ & Photothermal conversion storage \\
\hline & & $\begin{array}{l}\text { Wind energy } \\
\text { utilization }\end{array}$ & Wind power conversion storage \\
\hline & & $\begin{array}{l}\text { Geothermal energy } \\
\text { utilization }\end{array}$ & $\begin{array}{l}\text { Ground source heat pump } \\
\text { air-conditioning }\end{array}$ \\
\hline & & Hydraulic & Potential energy utilization \\
\hline
\end{tabular}




\begin{tabular}{|c|c|c|c|}
\hline & & Waste recycling & Combined heat and power \\
\hline & & Biomass energy & Straw combustion heat reuse \\
\hline \multirow{5}{*}{$\begin{array}{l}\text { Material } \\
\text { saving and } \\
\text { waste } \\
\text { disposal } \\
\text { system }\end{array}$} & \multirow[b]{2}{*}{$\begin{array}{l}\text { Material } \\
\text { saving }\end{array}$} & Material actuarial & Reduce the coefficient of safety \\
\hline & & $\begin{array}{l}\text { Local materials } \\
\text { utilization }\end{array}$ & Local material processing \\
\hline & \multirow{3}{*}{$\begin{array}{l}\text { Waste } \\
\text { treatment and } \\
\text { recycling }\end{array}$} & Garbage collection & Refuse classification \\
\hline & & $\begin{array}{l}\text { Organic solid waste } \\
\text { treatment }\end{array}$ & Microbial treatment \\
\hline & & $\begin{array}{l}\text { Inorganic solid waste } \\
\text { treatment }\end{array}$ & Concrete recycling \\
\hline \multirow{11}{*}{$\begin{array}{l}\text { Environment } \\
\text { optimization } \\
\text { system }\end{array}$} & \multirow{8}{*}{$\begin{array}{l}\text { Indoor } \\
\text { environment } \\
\text { optimization }\end{array}$} & $\begin{array}{l}\text { Natural lighting } \\
\text { optimization }\end{array}$ & Solar collector \\
\hline & & $\begin{array}{l}\text { Artificial lighting } \\
\text { optimization }\end{array}$ & Energy-saving lamps \\
\hline & & Noise source control & Avoid using noisy equipment \\
\hline & & Noise reduction & $\begin{array}{l}\text { Noise reduction technology, sound } \\
\text { insulation technology }\end{array}$ \\
\hline & & Air purification & Fresh air technology \\
\hline & & Air quality inspection & Harmful gas detection \\
\hline & & Air comfort & Personalized air supply \\
\hline & & $\begin{array}{l}\text { Electromagnetic } \\
\text { pollution control } \\
\text { system }\end{array}$ & $\begin{array}{l}\text { Electromagnetic inspection } \\
\text { technology }\end{array}$ \\
\hline & \multirow{3}{*}{$\begin{array}{l}\text { Outdoor } \\
\text { environment } \\
\text { optimization }\end{array}$} & Air quality inspection & Air inspection technology \\
\hline & & \begin{tabular}{|l|} 
Vegetation \\
conservation \\
\end{tabular} & Forest conservation \\
\hline & & Water conservation & Water microbial control \\
\hline \multirow{4}{*}{$\begin{array}{l}\text { Intelligent } \\
\text { control } \\
\text { system }\end{array}$} & \multirow{3}{*}{$\begin{array}{l}\text { Intelligent } \\
\text { building } \\
\text { system }\end{array}$} & Induction system & $\begin{array}{l}\text { Environmental information } \\
\text { collection }\end{array}$ \\
\hline & & Device remote control & E-card system \\
\hline & & Network access & Optical fiber, wireless network \\
\hline & $\begin{array}{l}\text { Digital } \\
\text { community }\end{array}$ & Virtual community & Community service support \\
\hline \multirow{5}{*}{$\begin{array}{l}\text { Economic } \\
\text { balance } \\
\text { system }\end{array}$} & \multirow{2}{*}{$\begin{array}{l}\text { Construction } \\
\text { cost balance }\end{array}$} & Material accounting & Material selection \\
\hline & & $\begin{array}{l}\text { Construction cost } \\
\text { control }\end{array}$ & Site modification cost \\
\hline & \multirow{2}{*}{$\begin{array}{l}\text { Operation } \\
\text { cost balance }\end{array}$} & $\begin{array}{l}\text { Operation system } \\
\text { control }\end{array}$ & Operation cost optimization \\
\hline & & Maintenance cost & Cost actuary \\
\hline & $\begin{array}{l}\text { Investment } \\
\text { recovery }\end{array}$ & $\begin{array}{l}\text { New material cost } \\
\text { recovery }\end{array}$ & Static and dynamic calculation \\
\hline
\end{tabular}

(1) Architectural design optimization system

Architectural design optimization system is the forefront of green ecological architecture integrated design, as well as the main means to release Passive ecological architecture. Through the implementation of various subsystems including Site optimization, function optimization, structural system optimization, equipment optimization, decoration optimization and construction plan control, it can help the building realize energy saving, material saving and land saving, to a certain extent.

(2) Energy design optimization system

Energy design optimization system is divided into two major parts: energy conservation and clean energy utilization. On the premise of reducing building energy consumption, architects should consider all the renewable energy resources available in the base where the building is located.

(3) Material saving and waste disposal system

Material saving and waste disposal system would provide a basis for architects in architectural design. The manufacturing process of building materials transportation and the energy consumed during construction constitute the embodied energy during building's construction period, and this part of energy needs to be considered in conjunction with the life cycle energy cycle of the building. 
(4) Environment design optimization system

Environment design optimization system mainly includes indoor environment such as sound, light, air, etc., and outdoor environment such as surrounding green environment. In the majority of cases, architects should consider to adopt the passive way to adjust indoor and outdoor environment as much as possible. In addition, a small number of high-efficiency systems can be used to cope with indoor climate regulation under extreme climatic conditions.

(5)Intelligent control system

Intelligent control system is the necessary guarantee for the implementation of many high-tech eco technological means. Architects can manipulate complex ecological building systems to achieve electronic control, that is, through a variety of sensor, to determine the changes in the outdoor environment in which the building is situated and then adjust accordingly, so that achieve the best use of renewable energy.

(6) Economic balance system

Economic balance system is to consider the economic rationality in the process of ecological building construction and use, and economic evaluation is also made for the implementation of other systems. For economic evaluation of ecological architecture, we must consider the whole life cycle of the building.

\section{References}

[1] Hansen H, Knudstrup M. The Integrated Design Process (IDP): a more holistic approach to sustainable architecture[C]// Action for sustainability - The 2005 World Sustainable Building Conference. 2005.

[2] Han X, Chao X U. Study on Countermeasures of Green Building Integrated Design Application Based on BIM Technology[J]. Northern Architecture, 2017.

[3] Xia W, Li D. METHODS AND PRACTICE OF GREEN BUILDING INTEGRATED DESIGN A Case Study of Qingdao Tianren Group Office[J]. Eco-city and Green Building, 2010.

[4] Yudelson J. Green building through integrated design[M]. Harbin Institute of Technology Press, 2014.

[5] Ilhan B, Yaman H. Green building assessment tool (GBAT) for integrated BIM-based design decisions[J]. Automation in Construction, 2016, 70:26-37.

[6] Xie X. Integrated design for green building in China : the obstacles and the way forward[J]. 2015.

[7] Wang Y, Zhang P Q. Research on the integrated design strategy of green building[J]. 2016, 63:02039. 